\title{
PENERAPAN PIDANA MATI TERHADAP TERPIDANA KASUS KORUPSI ${ }^{1}$
}

\author{
Warih Anjari \\ Fakultas Hukum Universitas 17 Agustus 1945 Jakarta \\ Jl. Sunter Podomoro, Jakarta Utara \\ a.warih11@gmail.com
}

\begin{abstract}
Corruption as extraordinary crime provides regulations regarding the death penalty for the perpetrators. However, the fact is that these provisions have never been applied by judges. The problems in this study are: why is the threat of capital punishment against convicted corruption based on Article 2 paragraph (2) UUTPK difficult to implement? The research method used is a normative juridical research method. The conclusion obtained is that the formulation of Article 2 paragraph (2) UUTPK relating to "emergency conditions" is difficult to fulfill. The formulation of the word "can be sentenced to death", provides an opportunity for the judge to impose the other heaviest criminal alternative which is not in the form of a criminal offense of life opportunity, namely a prison term with a certain period of time; or a maximum of 20 years or a life sentence.
\end{abstract}

Keywords: Death Penalty; Corruption; Application

\begin{abstract}
Abstrak
Korupsi sebagai extraordinary crime memberikan pengaturan mengenai pidana mati bagi pelakunya. Namun, faktanya ketentuan tersebut belum pernah diterapkan oleh Hakim dalam mengadili kasus korupsi. Oleh karena itu, korupsi tetap terjadi dan mengalami perluasan baik modus maupun pelakunya. Permasalahan dalam penelitian ini adalah mengapa ancaman pidana mati terhadap terpidana korupsi berdasarkan Pasal 2 ayat (2) Undang-Undang Pemberantasan Tindak Pidana Korupsi (UUTPK) sulit diterapkan? Metode penelitian yang digunakan adalah metode penelitian yuridis normatif. Hasil penelitian menunjukkan, perumusan Pasal 2 ayat (2) UUTPK yang berkaitan dengan "kondisi darurat" sulit dipenuhi unsurnya. Rumusan kata "dapat dipidana mati", memberikan peluang kepada hakim untuk menjatuhkan alternatif pidana terberat lainnya yang bukan berupa pidana penghilangan kesempatan hidup yaitu pidana penjara dengan jangka waktu tertentu; atau maksimum 20 tahun atau pidana seumur hidup.
\end{abstract}

Kata Kunci: Pidana Mati; Korupsi; Penerapan

\footnotetext{
${ }^{1}$ Artikel hasil penelitian mandiri yang dilakukan penulis pada tahun 2019.
} 


\section{A. Pendahuluan}

Korupsi merupakan istilah yang tidak asing terdengar di telinga bangsa Indonesia. Untuk memberantas korupsi, Indonesia telah memiliki lembaga khusus untuk melakukan penegakan hukum kasus korupsi. Lembaga pemberantasan korupsi dibentuk berdasarkan Undang-Undang Nomor 30 Tahun 2002 tentang Komisi Pemberantasan Korupsi (KPK). Dasar pemidanaan tindak pidana korupsi adalah Undang-Undang Nomor 31 Tahun 1999 tentang Pemberantasan Tindak Pidana Korupsi, yang telah diperbaharui dengan UndangUndang Nomor 20 Tahun 2001 tentang Perubahan atas Undang-Undang Nomor 31 Tahun 1999 tentang Pemberantasan Tindak Pidana (untuk selanjutnya disingkat UUTPK)

Pasal 2 ayat (2) UUTPK mengatur mengenai ancaman pidana mati bagi pelaku korupsi yang dilakukan dalam keadaan tertentu. Keadaan tertentu merupakan pemberatan bagi pelaku tindak pidana korupsi. Kriteria untuk pemberatan yaitu apabila tindak pidana korupsi dilakukan pada waktu negara dalam keadaan bahaya sesuai dengan undang-undang yang berlaku; pada waktu terjadi bencana alam nasional; sebagai pengulangan tindak pidana korupsi; atau pada waktu negara dalam keadaan krisis ekonomi dan moneter.

Dalam pemberantasan korupsi yang dipimpin oleh KPK, tahun 2018 merupakan tahun dimana penindakan terbanyak sepanjang sejarah KPK. Data KPK, sebelum operasi tangkap tangan (OTT) KPK terhadap pejabat Kementerian PUPR pada hari Jumat 28 Desember 2018, terdapat 91 perkara korupsi yang melibatkan anggota legislatif dan 28 perkara yang melibatkan kepala daerah aktif. Perkara tersebut merupakan hasil 30 OTT KPK dan pengembangan perkara (Media Indonesia, 2019). Operasi tangkap tangan sepanjang tahun 2019 dilakukan 21 kali di 14 daerah, dengan tersangka 76 orang (Komisi Pemberantasan Korupsi, 2019). Data tersebut menunjukkan penurunan OTT KPK dari 30 perkara pada tahun 2018, ke 21 perkara pada tahun 2019.

Banyaknya penindakan merupakan suatu dilema. Satu sisi merupakan kinerja positif dari KPK, namun sisi lainnya mengindikasikan korupsi semakin meningkat kuantitasnya. Peningkatan kuantitas korupsi merupakan kegagalan dari negara dalam menanggulangi tindak pidana korupsi. Korupsi tidak hanya terjadi di pusat pemerintahan, tetapi telah menyebar ke daerah, bahkan ke wilayah pedesaan. Hasil pengamatan Indonesian Corruption Watch (ICW), sejak 2015 hingga semester 1 tahun 2018 kurang lebih 181 kasus korupsi dana desa dengan kerugian sebesar Rp. 40,6 miliar. Demikian pula data dari Direktorat Jenderal Otonomi Daerah Kementerian Dalam Negeri, sejak tahun 2004 sampai dengan Oktober 2018 terdapat 434 kepala daerah terkena kasus hukum baik oleh KPK maupun kepolisian dan kejaksaan (Media Indonesia, 2019).

Hal ini tak berbanding lurus dengan angka Indeks Persepsi Korupsi Indonesia yang stag di angka 37 pada tahun 2016 dan tahun 2017. Namun pertumbuhan IPK Indonesia termasuk tertinggi di dunia. Kondisi ini jika dibandingkan dengan negara yang memiliki jumlah penduduk yang tinggi, misalnya Vietnam, Argentina, Brazil, Thailand, Nigeria, dan China Indonesia mengalami peningkatan skor sebanyak 17 poin, Vietnam 10 poin, Argentina 9 poin, Nigeria sebanyak 8 poin, dan China sebanyak 6 poin (Kompas, 2018).

Dalam melakukan penegakan kasus korupsi China telah menerapkan pidana mati bagi narapidana korupsi. Penerapan pidana mati terhadap pelaku korupsi di China dinilai efektif dalam rangka mengurangi tindak pidana korupsi. Fakta ini dapat dijadikan role model bagi Indonesia untuk menanggulangi tindak pidana korupsi (Wardani, K.A ; Wahyuningsih, 2017).

Undang-undang korupsi di Indonesia telah menetapkan ancaman pidana mati bagi pelaku korupsi, namun belum diimplementasikan. Bahkan sejak tahun 1999 secara legalitas ancaman pidana mati 
telah direkomendasikan oleh UUTPK, prakteknya sampai sekarang belum ada koruptor yang dijatuhi pidana mati (Yuhermansyah, E; Fariza, 2017). Oleh karena itu dalam rangka peningkatan kualitas penegakan hukum tindak pidana korupsi di Indonesia, maka kebijakan yang telah dituangkan tersebut didorong untuk dilaksanakan. Berkaitan dengan pendahuluan yang telah penulis kemukakan tersebut di atas, maka fokus permasalahan dalam tulisan ini, yaitu: mengapa ancaman pidana mati terhadap terpidana korupsi berdasarkan Pasal 2 ayat (2) UUTPK sulit diterapkan?

\section{B. Metode Penelitian}

Metode penelitian yang digunakan dalam penulisan ini adalah metode penelitian yuridis normatif atau penelitian doctrinal. Metode penelitian hukum normatif merupakan penelitian hukum yang menggunakan data utama berupa data yang diperoleh melalui studi pustaka. Metode ini dipilih karena obyek yang dikaji berupa norma, yaitu Pasal 2 UUTPK.

Metode pendekatan yang dilakukan dalam penelitian ini adalah statute approach dan conceptual approach. Statute approach karena yang menjadi sentral penelitian ini adalah aturan yang terkait dengan penjatuhan pidana mati terhadap pelaku korupsi sedangkan konsep yang digunakan dalam penulisan ini adalah konsep Hak Asasi Manusia (HAM). Metode analisis yang digunakan adalah deskriptif kualitatif dengan penafsiran gramatikal. Analisis merupakan penguraian yang menghasilkan hubungan sebab akibat dari suatu obyek yang diteliti. Proses analisis berdasarkan penalaran deduktif dan induktif, kemudian menghasilkan suatu argumentasi yang dicari dan bersifat ilmiah. Analisis dekriptif kualitatif artinya penulis berusaha menggambarkan kondisi yang ada melalui data sekunder, kemudian dikemukakan dalam bentuk uraian kalimat atau kata-kata. Hasil penggambaran tersebut penulis kaitkan dengan teori atau norma yang relevan dengan rumusan masalah dalam tulisan ini sebagai das sollen.

\section{Hasil dan Pembahasan}

\section{Penerapan Pidana Mati untuk Tindak Pidana Korupsi}

Pidana mati merupakan salah satu jenis pidana yang paling berat bagi pelaku tindak pidana. Pidana jenis ini berupa menghilangkan nyawa pelaku tindak pidana sebagai akibat dari perbuatan pidana yang dilakukannya. Dalam perkembangannya pidana mati menjadi kontroversi seiring dengan peningkatan pemahaman tentang Hak Asasi Manusia (HAM). Pidana mati di Indonesia masih mendapatkan legalitas. Pidana mati diatur dalam Buku 1 Pasal 10 KUHP sebagai salah satu jenis pidana pokok. Ketentuan pidana mati ini bersifat umum artinya dapat diterapkan baik dalam tindak pidana yang diatur dalam KUHP maupun tindak pidana yang diatur di luar KUHP kecuali peraturan tersebut mengatur berbeda. Salah satu tindak pidana yang diancam pidana mati dalam KUHP adalah pembunuhan berencana yang diatur dalam Pasal 340 KUHP. Tindak pidana khusus yang mengatur mengenai ancaman pidana mati di antaranya adalah UUTPK. Selain itu eksistensi pidana mati diperkuat dengan Putusan Mahkamah Konstitusi (MK) Nomor 2-3/PUU-V/2007 yang menyatakan hukuman mati tidak bertentangan dengan UUD 1945 (Lubis, 2009).

Pada tingkat internasional terdapat kecenderungan untuk menghapuskan pidana mati. Namun pidana mati masih boleh diterapkan pada tindak pidana yang bersifat "the most serious crimes" (Lubis, 2009). Pengaturan internasional tentang pidana mati ada dalam Pasal 6 ayat (1) International Convenan on Civil and Political Right (ICCPR) yang menyatakan tiap manusia berhak atas hak hidup yang melekat pda dirinya dan wajib dilindungi oleh hukum. Namun dalam ayat (2) menyatakan bahwa hukuman mati dapat diterapkan jika kejahatan bersifat serius (serious crime). Ketentuan internasional lainnya yang terkait 
dengan penerapan pidana mati adalah Pasal 3 Deklarasi Hak Asasi Manusia, (DUHAM) yang menyatakan bahwa setiap orang memiliki hak hidup, kebebasan, dan keamanan. Penafsiran secara argumentum $a$ contrario dari pasal tersebut, yaitu pidana mati menghilangkan hak hidup seorang pelaku kejahatan, sehingga tidak sesuai dengan substansi pasal dimaksud.

Berkaitan dengan makna serious crime tidak ditemukan indikator dalam ICPPR. Menurut Pembukaan Konvensi PBB Menentang Korupsi tahun 2003 (UNCAC), menyatakan korupsi merupakan masalah yang serius (serious crime). Di samping itu, berdasarkan konsideran UUTPK menyatakan bahwa tindak pidana korupsi yang selama ini terjadi secara meluas tidak hanya merugikan keuangan negara tetapi juga telah merupakan pelanggaran terhadap hak sosial dan ekonomi masyarakat secara luas, sehingga tindak pidana korupsi perlu digolongkan sebagai kejahatan yang pemberantasan harus dilakukan secara luar biasa. Oleh karena itu penerapan pidana mati masih dimungkinkan bagi pelaku korupsi menurut ketentuan internasional dan nasional.

Penjatuhan pidana mati bagi terpidana ada yang menyetujui dan ada yang tidak. Bagi yang menyetujui terdapat berbagai alasan, yaitu: (a) Penjatuhan pidana mati dianggap lebih efektif dari jenis pidana lainnya karena memiliki efek deteren terutama dalam kejahatan pembunuhan; (b) Pidana mati lebih hemat dari hukuman lainnya; (c) Pidana mati untuk mencegah tindakan balas dendam dari publik terhadap terpidana; (d) Hukuman yang dapat ditentukan kepastiannya (Jacob, 2017). Melalui penjatuhan pidana mati dimaksudkan akan memberikan efek jera kepada para pelaku dan bagi orang yang akan melakukan tindak pidana. Tujuan pemidanaan yang berupa penjeraan tercermin dalam Penjelasan UUTPK, yaitu: dalam rangka mencapai tujuan yang lebih efektif untuk mencegah dan memberantas tindak pidana korupsi, undang-undang ini membuat ketentuan pidana yang berbeda dengan undang-undang sebelumnya yaitu menentukan ancaman pidana minimum khusus, pidana denda yang lebih tinggi, dan ancaman pidana mati yang merupakan pemberat pidana.

Bagi yang tidak menyetujui pidana mati memberikan beberapa alasan, yaitu: (a) Menjatuhkan hukuman mati dapat menimbulkan ketidakadilan, karena kejahatan bukanlah hanya persoalan hukum pidana, namun bersifat sosiologis yang berkaitan dengan ekonomi, politik dan psikologis; (b) hukuman mati bertentangan dengan hak untuk hidup; (c) sistem peradilan pidana bukanlah sistem yang sempurna; (d) hukuman mati tidak dapat menghentikan kejahatan dan tidak menimbulkan efek jera; (e) adanya alternatif pemidanaan yang tidak mencabut nyawa terpidana dan bersifat berat, yang harus disosialisasikan; (f) Hukuman mati tidak sesuai dengan tujuan pemidanaan yang berupa pemasyarakatan (pendidikan dan resosialisasi narapidana) (Lubis, 2009).

Dalam tujuan pemidanaan terdapat konsep pencegahan (deterrence) yang dilakukan melalui pencegahan umum (algemen preventie theorien) dan pencegahan khusus (bijzondere preventie theorien) (Utomo, 2017). Pencegahan umum bertujuan untuk memberikan penjeraan kepada orang lain di luar pelaku agar tidak melakukan kejahatan. Sedangkan pencegahan khusus dimaksudkan agar pelaku menjadi jera untuk tidak mengulangi tindak pidana lagi. Penjatuhan pidana mati terhadap pelaku tindak pidana pada hakikatnya hanya pencegahan bersifat umum. Pencegahan khusus tidak akan tercapai karena pelaku dipidana mati.

Penjatuhan pidana mati bersinggungan dengan hak hidup yang merupakan Hak Asasi Manusia. Indonesia adalah salah satu negara yang menjunjung tinggi hak untuk hidup, yang ditempatkan pada hak yang bersifat non derogable right. Namun kepada pelaku kejahatan masih diterapkan pidana pencabutan hak hidup. Dalam perspektif kebijakan kriminal, penjatuhan pidana mati merupakan sarana penal untuk mencapai 
kesejahteraan masyarakat (Anjari, 2015). Namun, Indonesia yang merupakan negara yang berdasarkan Pancasila, tujuan penerapan pidana khususnya pidana mati harus selaras dengan nilai-nilai yang terkandung dalam Pancasila. Dalam menerapkan pidana mati harus memperhatikan keharmonisan antara kepentingan publik yang dilanggar dengan penjatuhan pidana (Anjari, 2017). Penerapan pidana mati dapat dilakukan terhadap tindak pidana yang melampaui batas kemanusiaan, mengancam hidup orang banyak, merusak tata kehidupan dan peradaban manusia, dan merusak perekonomian negara. Tindak pidana tersebut antara lain pembunuhan berencana, terorisme, narkoba bagi pengedar dan bandar, dan korupsi (Anjari, 2015).

Menurut penulis, penjatuhan pidana mati dalam UUTPK merupakan salah satu upaya memberantas tindak pidana korupsi secara serius dalam menciptakan kepastian, keadilan dan kemanfaatan hukum dimasyarakat. Penjatuhan pidana mati yang diatur dalam Pasal 2 ayat (2) UUTPK, tidak berlaku untuk tindak pidana korupsi secara umum, namun diberlakukan terhadap tidak pidana korupsi yang dilakukan dalam "keadaaan tertentu". Artinya penerapan pidana mati bersifat khusus terhadap korupsi dengan persyaratan tertentu. Secara normatif ancaman pidana mati bagi pelaku korupsi telah ada sejak tahun 1999, namun dalam praktiknya sampai saat ini belum ada pelaku korupsi yang dijatuhi pidana mati (Yuhermansyah, E; Fariza, 2017).

\section{Kendala Dalam Menerapkan Pidana Mati Terhadap Pelaku Korupsi}

Pidana mati di Indonesia diterapkan berdasarkan Pasal 10 KUHP. Dalam Pasal tersebut pidana mati merupakan jenis pidana pokok yang terberat. Pidana mati di Indonesia dilakukan dengan ditembak mati. Pelaksanaan pidana mati berdasarkan Undang-Undang Nomor 2 PNPS tahun 1964 tentang Tata Cara Pelaksanaan Pidana Mati yang Dijatuhkan oleh Pengadilan di Lingkungan Peradilan Umum dan Militer. Keberadaaan peraturan tersebut mengindikasikan pidana mati masih diterapkan di Indonesia.

Praktiknya penerapan pidana mati oleh hakim dilakukan pada kasus tindak pidana umum dan pidana khusus. Pada tindak pidana umum pidana mati dijatuhkan pada kasus pembunuhan yang bersifat kejam, misalnya pada pembunuhan berencana, korban pembunuhan tidak hanya satu korban, dan sebagainya. Pada tindak pidana khusus pidana mati dapat dijatuhkan terhadap pelaku tindak pidana korupsi. Pidana mati terhadap pelaku korupsi diatur dalam Pasal 2 ayat (2) UUTPK, yang menyatakan: "Dalam hal tindak pidana korupsi sebagaimana ayat (1) dilakukan dalam keadaaan tertentu pidana mati dapat dijatuhkan". Selanjutnya yang dimaksud dengan "keadaan tertentu" dijelaskan dalam Penjelasan Pasal 2 ayat (2) UUTPK adalah apabila korupsi dilakukan: pada waktu negara dalam keadaan bahaya menurut ketentuan undang-undang yang berlaku; pada waktu terjadi bencana nasional; sebagai pengulangan tindak pidana korupsi; atau pada waktu negara dalam keadaan krisis ekonomi dan moneter. Dengan demikian secara normatif telah ada pengaturan yang dapat dijadikan dasar oleh hakim untuk menjatuhkan pidana mati terhadap pelaku tindak pidana korupsi. Artinya dalam perspektif legalitas tidak ada keraguan lagi untuk mempersoalkan legalisasi penerapan pidana mati bagi pelaku tindak pidana korupsi.

Untuk menjatuhkan pidana kepada pelaku yang diduga melakukan tindak pidana harus dipenuhi unsur-unsur tindak pidana yang didakwakan kepada pelaku. Setiap perbuatan pidana terdapat unsur obyektif (criminal act/actus reus) dan unsur subyektif (criminal responsibility/mens rea). Kedua unsur ini tercantum dalam pasal yang disangkakan kepada pelaku tindak pidana. Unsur obyektif merupakan perbuatan pidana dan unsur subyektif merupakan sikap batin pelaku. Perbuatan pelaku merupakan syarat pertama untuk memungkinkan seseorang dijatuhi pidana (Sudarto, 2009). Tanpa 
perbuatan (manusia) tidak akan dapat dijatuhi pidana.

Perbuatan yang dapat dipidana diatur dalam undang-undang. Perbuatan yang tidak tercantum dalam undang-undang pidana tidak dapat dijatuhi pidana. Hal ini merupakan konsekuensi penggunaaan asas legalitas berdasarkan Pasal 1 ayat (1) KUHP. Pengaturan perbuatan yang dapat dipidana dalam undang-undang pidana merupakan dasar dari pemidanaan. Oleh karena itu perumusan perbuatannya harus bersifat rigid dan pasti. Ketidakpastian perumusan perbuatan pidana dalam perundangan akan mengakibatkan kesulitan menentukan perbuatan mana yang dimaksud sehingga bersifat multitafsir. Selain itu akan menimbulkan ketidaktenteraman bagi masyarakat (Sudarto, 2009).

Perumusan tindak pidana korupsi yang dapat dijatuhi pidana mati telah tercantum di dalam Pasal 2 ayat (2) UUTPK. Perbuatan korupsi yang dilakukan pelaku harus memenuhi unsur-unsur yang tercantum dalam Pasal 2 ayat (2) UUTPK. Artinya perbuatan pelaku secara konkrit harus mempunyai sifat-sifat atau ciri-ciri dari tindak pidana yang tercantum secara abstrak dalam Pasal 2 ayat (2) Undang-Undang Nomor 31 Tahun 1999 tentang Pemberantasan Tindak Pidana Korupsi.

Perumusan Pasal 2 ayat (2) UUTPK mengacu pada Pasal 2 ayat (1) UUTPK. Tindak pidana korupsi yang dapat dijatuhi pidana mati merupakan tindak pidana korupsi berdasarkan Pasal 2 ayat (1) UUTPK, yang dilakukan dalam keadaan darurat berdasarkan Pasal 2 ayat (2) UUTPK. Perumusan "kondisi darurat" ini yang menyulitkan dalam pemenuhan unsurnya. Menurut Penjelasan Pasal 2 ayat (1) UUTPK, terdapat 4 kategori keadaaan darurat, yaitu: pada waktu negara dalam keadaan bahaya menurut ketentuan undangundang yang berlaku; pada waktu terjadi bencana nasional; sebagai pengulangan tindak pidana korupsi; atau pada waktu negara dalam keadaan krisis ekonomi dan moneter. Keempat kondisi tersebut merupakan unsur agar pelaku korupsi dapat dijatuhi pidana mati.

Keempat kondisi keadaan darurat tersebut terjadi dalam keadaaan yang khusus. Jika keadaan darurat dalam perbuatan pelaku korupsi tidak ada maka hakim tidak dapat menjatuhkan pidana mati terhadap pelakunya. Hal ini mengindikasikan penjatuhan pidana mati dapat diterapkan dalam kondisi yang khusus pula. Artinya dalam pengaturan hukum pidana, penjatuhan pidana mati tidak lagi bersifat umum. Walaupun pidana mati secara positif masih diatur dalam KUHP yang bersifat umum. Namun penerapannya dilakukan dengan penuh pertimbangan. Kasus yang dijatuhi pidana mati adalah pembunuhan berencana, narkotika, terorisme, dan kekerasan seksual anak yang menyebabkan kematian. Di samping itu undang-undang yang sering diterapkan pidana mati adalah Undang-Undang Nomor 35 tahun 2009 tentang Narkotika, UndangUndang Nomor 15 Tahun 2003 tentang Terorisme, dan KUHP (BBC, 2017). Untuk mendukung pemberantasan korupsi seharusnya ancaman pidana mati ditentukan bukan dalam kondisi khusus, namun diatur secara umum dalam undang-undang korupsi dan perumusan unsurnya lebih sederhana. Hal ini mengingat korupsi di Indonesia yang dikatakan sudah akut (RI, 2019). Selayaknya pidana mati dapat diterapkan kepada koruptor.

Penerapan pidana mati kepada koruptor tidak semata-mata bertujuan mengurangi kejahatan korupsi, namun dimaksudkan agar dapat menimbulkan pertobatan atau efek penjeraan pada pelaku dan masyarakat. Hal ini sejalan dengan pendapat Foucoult yang menyatakan masyarakat tidak boleh hanya berpikir tujuan pemidanaan adalah mengurangi kejahatan, namun hukuman mengacu pada kondisi sosial, sistem politik, dan kepercayaan agama; sehingga tindak hukum dapat sangat toleran atau dapat sangat keras dan kejam diarahkan pada individu atau komunitas, dan terakhir dapat membuat pertobatan atau efek jera bagi individu atau komunitas (Sabdo, 2015). 
Tindak pidana korupsi merupakan tindak pidana yang tidak secara langsung dapat mengenai korban (indirect victim), dan korban bersifat menyebar (difusian victim). Namun korban akan sangat menderita karena hak-hak yang seharusnya diterima tidak terlaksana akibat dari perbuatan korup pelaku. Misalnya korupsi dana desa. Dana desa yang dapat digunakan untuk meningkatkan kesejahteraan rakyat, karena dikorupsi oleh oknum tertentu berakibat kesejahteraaan tidak dapat dirasakan oleh warga desa. Akibatnya terhambatnya penambahan penghasilan masyarakat miskin dan pembangunan infrastruktur desa (Kompasiana, 2016).

Pada dasarnya ancaman pidana mati yang dicantumkan dalam perundang-undang secara teoritis mengandung aspek pencegahan (deterence). Artinya dengan pencantuman ancaman pidana mati terhadap koruptor dalam perundang-undangan, diharapkan dapat menakut-nakuti orang yang akan melakukan tindak pidana korupsi sehingga korupsi dapat tercegah. Namun jika tidak ada penerapannya maka orang tidak akan percaya dan sebaliknya akan menimbulkan keberanian untuk melakukan korupsi.

Negara yang telah menerapkan pidana mati pada kasus korupsi adalah China. China berhasil melakukan penegakan hukum terhadap kasus korupsi tanpa pandang bulu termasuk menghukum mati koruptor. Sedangkan bagi Indonesia hukuman mati bagi koruptor sekedar wacana walaupun telah diatur dalam hukum positif (Kaka, 2018). Oleh karena itu dibutuhkan perumusan tindak pidana korupsi dengan diancam dengan pidana mati, yang mudah dibuktikan dalam persidangan. Sehingga hakim akan lebih mudah menerapkan pidana mati kepada koruptor.

Kualitas dan kuantitas pidana yang dapat dijatuhkan oleh hakim terikat dengan ancaman pidana yang telah tercantum dalam rumusan undang-undang pidana. Pengaturan ancaman pidana dalam sistem hukum pidana Indonesia adalah adanya batas minimum dan maksimum. Batas minimum terdiri dari minimum umum dan minimum khusus. Minimum umum adalah 1 (satu) hari penjara dan minimum khusus diatur dalam tindak pidana khusus. KUHP tidak mengenal adanya minimum khusus. Ancaman pidana maksimum terdiri dari maksimum umum dan maksimum khusus. Maksimum umum meliputi pidana penjara 20 tahun, pidana seumur hidup dan pidana mati. Maksimum khusus diatur dalam ancaman masingmasing pasal. Dalam Pasal 2 ayat (2) UUTPK merumuskan: "...dapat dijatuhi pidana mati”. Rumusan ini tidak mewajibkan hakim untuk menjatuhkan pidana mati terhadap korupsi yang dilakukan pada "keadaaan tertentu", seperti yang disyaratkan dalam pasal tersebut. Sehingga hakim dapat memilih alternatif ancaman pidana lain yang berat tetapi bukan pidana mati, yaitu pidana penjara 20 tahun atau pidana seumur hidup.

Hakim dalam menjatuhkan pidana memiliki batas mulai dari ancaman pidana minimum sampai dengan maksimum (indeterminite sentence). Untuk tindak pidana umum yang pengaturannya dalam KUHP tidak dikenal adanya minimum khusus, sehingga batas hakim dalam menjatuhkan pidana untuk tindak pidana umum dimulai dari ancaman pidana minimum 1 (satu) hari sampai dengan maksimum khusus yang diatur dalam pasal masing-masing atau maksimum umum. Sedangkan untuk tindak pidana khusus yang diatur di luar KUHP batas hakim dalam menjatuhkan pidana meliputi minimum umum atau minimum khusus sampai maksimum umum atau maksimum khusus. Sistem hukum pidana umum di Indonesia tidak mengenal pembatasan minimum khusus pada setiap rumusan tindak pidananya. Pengaturan ancaman pidana minimum khusus dalam UUTPK artinya hakim tidak boleh menjatuhkan pidana di bawah dari sanksi pidana minimum yang ditetapkan dalam undang-undang. Hal ini dimaksudkan untuk membuat para pelaku korupsi jera melakukan tindak pidana korupsi (Sudirman, 2015). 
Pengaturan ancaman pidana dalam Pasal 2 ayat (2) UUTPK mengakibatkan hakim memiliki alternatif pemidanaan karena perumusannya bersifat indefinite sentence (tidak pasti). Dalam hal ini, hakim dapat menjatuhkan pidana penjara maksimum 20 tahun atau pidana seumur hidup atau pidana mati sepanjang rumusan mengaturnya. Dalam menjatuhkan putusan pemidanaan hakim bersifat mandiri (Pasal 3 ayat (1) Undang-Undang Nomor 28 Tahun 2009 tentang Kekuasaan Kehakiman) dengan menyampaikan pertimbangan dalam menjatuhkan putusan tersebut. Jika dalam rumusan pasal yang didakwakan bersifat alternatif maka hakim dapat menentukan berdasarkan alternatif yang diatur dalam rumusan pasal tersebut. Sehingga sebaiknya perumusan sanksi pada Pasal 2 ayat (2) UUTPK bersifat pasti (definite sentence), untuk menghindari kewenangan hakim yang dapat memilih sanksi yang bersifat alternatif tersebut. Di samping itu dalam perkara pidana hakim memutus perkara harus berdasarkan rumusan tindak pidana yang telah ditetapkan dalam perundang-undangan dan dilarang melakukan analog (Hiariej, 2009). Hal ini merupakan konsekuensi dari penggunaan asas legalitas dalam KUHP.

Penjatuhkan pidana kepada pelaku tindak pidana oleh hakim dilakukan dalam beberapa tahap, yaitu: Tahap pertama merupakan tahap melakukan analisis perbuatan pidana. Pada tahap ini, hakim menganalisis apakah terdakwa melakukan perbuatan pidana atau tidak, dimana perbuatan tersebut diatur dalam suatu rumusan aturan pidana. Tahap kedua merupakan tahap menganalisis pertangungjawaban pidana. Pada tahap ini, jika terdakwa dinyatakan terbukti melakukan suatu perbuatan pidana, hakim akan melakukan analisis apakah terdakwa mampu untuk mempertanggungjawabkan perbuatan pidana yang dilakukannya. Tahap ketiga merupakan tahap penentuan pidana. Hakim akan menjatuhkan pidana apabila pelaku telah memenuhi unsur-unsur dari pasal undang-undang yang dilanggar (Utomo, 2017). $\begin{array}{lcr}\text { Dalam menjatuhkan pidana pada } \\ \text { putusannya } & \text { secara konkrit } & \text { hakim } \\ \text { melaksanakan } & \text { kemandiriannya } & \text { dengan }\end{array}$ beberapa kriteria, yaitu: (a) Memilih beratnya pidana yang bergerak dari minimum ke maksimum berdasarkan rumusan tindak pidananya; (b) memilih pidana pokok yang patut dijatuhkan apakah pidana mati, pidana penjara, pidana kurungan atau pidana denda sesuai dengan berat ringannya perbuatan yang dilakukan; (c) sebelum hakim tiba pada pemilihan butir 1 dan 2, ia dapat memilih apakah menjatuhkan pidana pokok dan pidana tambahan atau hanya menjatuhkan pidana bersyarat saja, manakala ia memandang lebih bermanfaat bagi masyarakat dan terpidana jika dijatuhkan pidana bersyarat saja (Wijaya, 2008). Kriteria kemandirian hakim dalam menjatuhkan pidana mengindikasikan dalam menjalankan kekuasaannya hakim tidak sepenuhnya memiliki kemandirian. Kemandirian hakim yang diatur dalam Pasal 3 ayat (1) dan (2) Undang-Undang Nomor 48 Tahun 2009 tentang Kekuasaan Kehakiman dibatasi oleh sistem pemerintahan, politik, ekonomi dan peraturan perundang-undangan yang mengatur kemerdekaan tersebut (Utomo, 2017). Demikian pula terhadap penjatuhan pidana mati bagi pelaku korupsi. Hakim dibatasi oleh ketentuan perundang-undangan yang tercantum dalam Pasal 2 ayat (2) UUTPK.

Dalam praktik pelaksanaan pidana mati di Indonesia tertunda. Banyak faktor penyebabnya, misalnya terpidana belum melaksanakan semua haknya. Hal ini merupakan salah satu faktor yang harus dihindari karena berakibat pada tujuan pemidanaan tidak tercapai. Preseden tidak tertundanya pidana mati, menjadikan efek penjeraan dan pertobatan menjadi lemah. Pelaksanaan pidana mati harus disegerakan dilaksanakan sesuai bunyi putusan sepanjang hak-hak terpidana telah dilaksanakan. Di samping itu daftar tunggu eksekusi pidana mati merupakan bentuk penyiksaan baik secara fisik maupun psikologis. Menurut William Schabas, 
menyatakan bahwa penundaan hukuman mati menambah efek psikologis ketercabutan seseorang yang terjadi tidak hanya dari masyarakat tapi dari sesama narapidana. Pengadilan Hak Asasi Manusia Uni Eropa menetapkan keputusan melalui kasus Soering vs The United Kingdom tahun 1989, dan menyatakan dalam putusannya bahwa penundaan hukuman merupakan pemenjaraan berkepanjangan dengan situasi penekanan dan kesengsaraan terus menerus (Ginting, 2018).

Selain perangkat perundang-undang yang memadai, pemberantasan tindak pidana korupsi dipengaruhi oleh penegak hukum. Aparat penegak hukum harus mengimplementasikan dan menerapkan kaidah hukum formal dan materiil dalam menjatuhkan sanksi pidana terhadap pelaku tindak pidana korupsi (Utomo, 2017). Kaidah hukum formal dan material dimaksud adalah UUTPK. Untuk penjatuhan pidana mati diatur dalam Pasal 2 ayat (2) UUTPK. Sehingga perlunya penegasan ancaman pidana mati yang bersifat lebih pasti dalam UUTPK. Hal ini dimaksudkan agar hakim tidak mempunyai alternatif penjatuhan pidana lain selain menjatuhkan pidana mati pada pelaku tindak pidana korupsi. Setelah dijatuhkan pidana mati, maka eksekusi pidana mati terhadap pelaku korupsi harus segera dilaksanakan. Hal ini mengingat penundaan eksekusi mati merupakan perpanjangan kesengsaraan bagi terpidana.

Oleh karena itu Pasal 2 ayat (2) UUTPK harus segera dilakukan perubahan mengenai perumusan unsur tindak pidana korupsi yang dapat dijatuhi pidana mati. Sehingga hakim sebagai ujung tombak penegakan hukum korupsi dapat menjatuhkan pidana mati dengan lebih pasti. Hal ini mengingat dampak sosial korupsi dapat berupa: pembusukan atas watak aparat penegak hukum sehingga menihilkan harapan atas keadilan, melahirkan watak politisi yang rakus, menggagalkan tujuan program pemerintah dalam meningkatkan kesejahteraan rakyat, membahayakan stabilitas atau keamanan negara dan masyarakat, menghancurkan segenap sendisendi penting dalam negara, mengakibatkan kerusuhan yang sangat ganas dan cenderung menjadikan sebagian orang menjadi biadab, menyebabkan disintegrasi bangsa, merusak moralitas warga masyarakat dan mempengaruhi mind set generasi muda bahwa korupsi dianggap sebagai suatu budaya baru di Indonesia (Sudirman, 2015).

Dalam perkembangan praktik pengadilan terhadap eksistensi pidana mati telah ditetapkan dengan putusan Mahkamah Konstitusi (MK) Nomor 2-3/PUU-V/2007. Putusan ini tentang pengujian hukum mati dalam Pasal 80-82 Undang-Undang Nomor 22 Tahun 1997 tentang Narkotika terhadap Pasal 28A, 28 I ayat (1) dan (4), serta Pasal 28 D ayat (1) UUD 1945. Dalam putusan tersebut dinyatakan bahwa ketentuan Pasal 80 ayat (1) huruf a, ayat (2) huruf a, ayat (3) huruf a, Pasal 81 ayat (3) huruf a, Pasal 82 ayat (1) huruf a, ayat (2) huruf a, dan ayat (3) huruf (a) dalam Undang-Undang Narkotika, sepanjang yang mengenai ancaman pidana mati tidak bertentangan dengan Pasal 28 A dan Pasal 28 I ayat (1) UUD NRI Tahun 1945. Walaupun pidana mati merupakan hukuman yang paling ekstrim yang dijatuhkan kepada terpidana, karena bila telah dilaksanakan pidana mati bersifat akhir dan tidak dapat diubah lagi. Berdasarkan putusan MK Nomor 2-3/PUU$\mathrm{V} / 2007$ tersebut, eksistensi pidana mati untuk terpidana narkotika diperkuat, namun dengan kriteria kejahatan yang bersifat the most serious crimes sama seperti kejahatan genoside dan pelanggaran HAM yang bersifat "adversarily effect the economic, cultural, and political foundantion of society".

Untuk tindak pidana korupsi, berdasarkan UNCAC tahun 2003 yang telah diratifikasi dengan Undang-undang Nomor 7 Tahun 2006 tentang Pengesahan United Nation Convention Againts Corruption tanggal 18 April 2006, menyatakan korupsi sebagai persoalan yang serius dan mengancam stabilitas dan keamanan masyarakat, melecehkan lembaga-lembaga dan nilai-nilai demokrasi, nilai etika dan 
keadilan, serta membahayakan pembangunan berkelanjutan dan aturan hukum (UNCAC). Hal ini sesuai dengan ketentuan Pasal 6 ayat (2) ICCPR, yang masih membolehkan penerapan pidana mati pada jenis kejahatan yang bersifat serius. Mendasarkan pada ketentuan tersebut, pidana mati tidak bertentangan dengan ketentuan Internasional. Dalam pengaturan pidana mati berdasarkan Pasal 2 ayat (2) UUTPK, juga telah mengikuti kecenderangan umum dari negara-negara untuk menghapuskan pidana mati (Resolusi Majelis Umum PBB Nomor 44/128). Ancaman pidana mati dalam Pasal 2 ayat (2) UUTPK, tidak lagi menjadi pidana pokok , namun merupakan pidana yang bersifat khusus.

\section{Simpulan dan Saran}

Berdasarkan pembahasan yang penulis telah kemukakan, maka kesimpulan dapat dikemukakan sebagai berikut: Penjatuhan pidana mati terhadap pelaku tindak pidana korupsi berdasarkan Pasal 2 ayat (2) UUTPK sulit diterapkan terutama pada unsur "kondisi darurat". Hal ini karena dalam menjatuhkan pidana unsur "kondisi darurat" harus dapat dipenuhi seperti yang tercantum dalam rumusan undang-undang. Jika perbuatan pelaku secara konkrit tidak dapat memenuhi unsur yang tercantum dalam rumusan undang-undang secara abstrak maka tidak dapat dijatuhi pidana. Rumusan kata "dapat dipidana mati memberikan peluang kepada hakim untuk menjatuhkan alternatif pidana terberat lainnya yang bukan berupa penghilangan kesempatan hidup. Sehingga perumusannya sebaiknya bersifat definite sentence.

Sehubungan dengan kesimpulan tersebut, maka saran yang perlu disampaikan yaitu segera diperlukan revisi Pasal 2 ayat (1) UUTPK. Revisi dilakukan terhadap perumusan unsur tindak pidana korupsi yang dapat dijatuhi pidana mati. Kata "..dapat.." dalam rumusan Pasal 2 ayat (1) UUTPK diubah menjadi "...harus..." atau "...wajib..". Hindari alternatif sanksi lain yang merupakan ancaman pidana selain penjatuhan mati. Hal ini karena ancaman pidana mati untuk kejahatan korupsi tidak bertentangan dengan ketentuan nasional dan internasional serta diharapkan deterrence effect dapat tercapai.

\section{DAFTAR PUSTAKA}

Anjari, W. (2015). Penjatuhan Pidana Mati di Indonesia Dalam Perspektif Hak Asasi Manusia. Retrieved from https://media.neliti.com/media/publicati ons/247155-penjatuhan-pidana-mati-diindonesia-dalam-dc4b10c5.pdf

Anjari, W. (2017). Penjara Terhadap Dokter Dalam Perspektif Mengikatnya Kekuatan Putusan Mahkamah Konstitusi dan Pemidanaan Integratif. Jurnal Yudisial, 10(1), 59-78.

BBC. (2017). Ancaman Hukuman Mati di Indonesia: Dari Korupsi Sampai Kekerasan Seksual. Retrieved January 10, 2019, from https://www.bbc.com/indonesia/trensosi al-41569770

Ginting, M. (2018). Masa Depan Hukuman Mati. Retrieved January 10, 2019, from https://kolom.tempo.co/read $/ 1134713 / \mathrm{m}$ asa-depan-hukuman-mati/full\&view $=$ ok

Hiariej, E. Q. . (2009). Asas Legalitas \& Penemuan Hukum Dalam Hukum Pidana. Jakarta: Erlangga.

Jacob, E. R. T. (2017). Pelaksanaan Pidana Mati Menurut Undang-Undang Nomor 2/PNPS/1964. Lex Crimen, 1(1), 98 105.

Kaka, Y. (2018). Berantas Korupsi: Belajarlah dari China, 1 April 2018. Retrieved January 11, 2019, from https://kumparan.com/yuliuskaka/berantas-korupsi-belajarlah-darichina

Komisi Pemberantasan Korupsi. (2019). Buku Laporan Tahunan KPK tahun 2019. Retrieved from https://www.kpk.go.id/images/pdf/Lapo 
ran-Tahunan-KPK-2019-Bahasa.pdf

Kompas. (2018). Ketua KPK: Pertumbuhan Indeksa Persepsi Korupsi Indonesia Tertinggi di Dunia. Retrieved January 7 , 2019, from https://nasional.kompas.com/read/2018/ 12/04/10400111/ketua-kpkpertumbuhan-indeks-persepsi-korupsiindonesia-tertinggi-di-dunia

Kompasiana. (2016). Dampak-Dampak Terjadinya Korupsi. Retrieved January 14, 2019, from https:/www.kompasiana.com/wikkef/5 8188eb08f7e61fc28022289/dampakdampak-terjadinya-korupsi

Lubis, T. M. (2009). Hukuman Mati Pasca Putusan Mahkamah Konstitusi. Jurnal Hukum Dan Pembangunan, 39(2), 255270.

Media Indonesia. (2019). Resolusi Membunuh Korupsi. Retrieved January 7, 2019, from http://mediaindonesia.com/editorials/det ail_editorials/1574-resolusi-membunuhkorupsi

RI, K. D. N. (2019). Mendagri: Korupsi di Indonesia Sudah Akut. Retrieved January 11, 2019, from https://www.kemendagri.go.id/index.ph p/blog/27805-Mendagri-Korupsi-di-
Indonesia-Sudah-Akut

Sabdo, B. (2015). Politik Hukum Pidana Mati. Yogyakarta: Pohon Cahaya.

Sudarto. (2009). Hukum Pidana I. Semarang: Yayasan Sudarto.

Sudirman, A. (2015). Eksistensi Pidana Minimum Khusus Sebagai Sarana Penanggulangan Tindak Pidana Korupsi. Jurnal Masalah-Masalah Hukum, 44(3), 316-325.

Utomo, D. S. .; N. W. .; S. (2017). Penjatuhan Pidana Bersyarat Bagi Koruptor Dalam Perspektif Upaya Pemberantasan Tindak Pidana Korupsi Di Indonesia. Jurnal Pasca Sarjana Hukum UNS, (2), 101-116.

Wardani, K.A; Wahyuningsih, S. . (2017). Kebijakan Formulasi Hukum Pidana Terhadap Pelaku Tindak Pidana Korupsi di Indonesia. Jurnal Hukum Khaira Ummah, 12(4), 951 - 958.

Wijaya, F. (2008). Peradilan Korupsi Teori dan Praktek. Jakarta: Penaku.

Yuhermansyah, E ; Fariza, Z. (2017). Pidana Mati Dalam Undang-Undang Tindak Pidana Korupsi (Kajian Teori Zawajir dan Jawabir). Legitimasi, 6(1), 156174. 